\title{
STRATEGI MENGAJAR ACADEMIC WRITING UNTUK MENINGKATKAN KUALITAS KARYA ILMIAH MAHASISWA DI JURUSAN PENDIDIKAN BAHASA INGGRIS, UNIVERSITAS WIDYA DHARMA KLATEN
}

\author{
Fibriani Endah Widyasari', Umi Sholihah ${ }^{2}$ \\ Universitas Widya Dharma Klaten \\ e-mail : fienwi@unwidha.ac.id
}

\begin{abstract}
Abstrak
Karya ilmiah menjadi tututan bagi sivitas akademika, tanpa terkecuali bagi mahasiswa guna meningkatkan kualitas berfikir secara kritis dan sistematis sebagai media refleksi untuk mengukur kemampuan dari bidang ilmu yang telah dipelajari selain untuk mengangkat kredibilitas institusi pendidikan yang mulai bersaing di tingkat internasional. Kenyataan ini tidaklah mudah untuk direalisasikan karena banyaknya faktor yang mempengaruhi pencapaiannya, mulai dari sumber daya manusia, kurangnya pengetahuan, minimnya strategi mengajar yang tepat yang mampu menjembatani kebutuhan mereka dalam menulis karya ilmiah. Dengan pertimbangan kebutuhan karya ilmiah yang harus dipenuhi oleh mahasiswa, program studi pendidikan bahasa Inggris Universitas Widya Dharma Klaten memberikan pengetahuan tentang Academic Writing secara dini dan terstruktur dengan strategi mengajar yang tepat bagi mahasiswa supaya mampu menghasilkan karya ilmiah baik untuk kebutuhan kompetisi, tugas menulis maupun tugas akhir mereka berupa skripsi pada mata kuliah Writing I sampai dengan VI. Penelitian ini bertujuan untuk mengetahui Proses pengajaran materi Academic Writing guna meningkatkan kualitas karya ilmiah bagi mahasiswa program studi pendidikan bahasa Inggris di Universitas Widya Dharma Klaten, Penelitian ini merupakan merupakan penelitian kualitatif. Pengumpulan data akan dilakukan secara langsung di kelas yang sudah ditentukan melalui observasi, wawancara, dan dokumentasi berupa hasil menulis mahasiswa. Data kualitatif akan dianalisis melalui reduksi data, pemaparan data dan proses validasi

Kata Kunci : Academic writing, karya ilmiah, strategi mengajar.
\end{abstract}

\begin{abstract}
Academic writing is the obligation should be done by all the students to encourage their critical thinking and systematically as the measurement of the material has been learnt and the tool to improve the institution credibility as the academic writing becomes the competition among students in the wild range of categories. In fact, the academic writing achievement is way too hard for students concerning to the many factors influenced, the limited number of the human resources to teach academic writing, the lack of knowledge about academic writing and less of appropriate teaching strategies to improve students ability in writing academically because of its difficulties have become the major factors of students' low capability in academic writing. Realizing academic needs require students to write some sort of academic writing, the English department of study program decided to teach students as early as possible and provide the appropriate teaching strategies as it needed in the field of competition, assignments and research and it is implemented into curriculum given in the form of Writing I to Writing VI in each semester which should be mastered by student in order to develop their academic writing skills. This study is the qualitative research which collecting the data by conducting observation, interview and documentation. The data collected was analyzed through data reduction, display and also through data triangulation.
\end{abstract}

Keywords: Academic writing, Teaching Strategies. 


\section{PENDAHULUAN}

Seorang mahasiswa pendidikan bahasa Inggris bisa dikatakan berhasil dalam belajar apabila mampu menguasai empat kemampuan atau keahlian dalam belajar bahasa, yaitu menulis, mendengar, berbicara dan membaca. Masing-masing kemampuan berbahasa diberikan secara terstruktur atau berjenjang bagi mahasiswa pendidikan bahasa Inggris sejak mereka duduk di semester pertama hingga mereka menduduki semester tujuh. Kemampuan menulis menjadi salah satu keahlian yang harus dikuasai mahasiwa dengan maksimal berkaitan dengan tugas akhir mahasiswa atau skripsi yang berupa tulisan dengan kaidah-kaidah ilmiah yang harus dipenuhi. Mahasiswa sangat diharapkan mampu menghasilkan sebuah karya atau tulisan yang mampu menuangkan ide dan pikiran mereka sesuai bidang ilmu yang mereka pelajari secara sistematis dan memenuhi kaidah ilmiah sebagai refleksi dan indikator keberhasilan belajar mereka selama duduk di bangku perkuliahan. Hal ini dikuatkan oleh teori Harmer (1998: 79) bahwa ada beberapa alasan untuk mengajar menulis bagi siswa yang berbahasa Inggris sebagai bahasa asing yaitu penguatan, pengembangan bahasa, model mengajar, dan yang paling penting adalah menulis merupakan keahlian tersendiri yang harus dikuasai.

Menulis merupakan kegiatan yang sangat ditakutkan oleh mahasiswa karena tingkat kesulitan dan kompleksitas yang sangat tinggi, seperti dikutip dari teori yang disampaikan oleh Fabb dan Durant (2005: 26) bahwa menulis berarti mengonstruksi karena menulis bukan sekedar mengeluarkan ide atau pendapat secara bebas, melainkan proses mengomposisi atau membangun sesuatu. Menulis melibatkan proses rekonstruksi yang berkelanjutan yang berarti menulis harus melalui proses pengeditan dan revisi berulang ulang baik dari isi tulisan, bahasa, maupun aspek penulisan yang lain. Menulis merupakan cara berpikir seseorang, menulis dipandang sebagai alat untuk mambantu penulis menuangkan ide yang sistematis dan berstruktur yang menjadi tolak ukur pembaca untuk melihat cara berpikir si penulis. Yang tidak kalah penting adalah menulis sangat berbeda dari berbicara, pada waktu berbicara pendengar pada saat yang bersamaan dapat memberikan interupsi dan pembicara pada saat itu pula dapat melakukan klarifikasi mengenai berbagai hal yang dibicarakan sehingga mampu menghindari kesalahpahaman dan pemahaman akan diperoleh dengan cepat pula. Semua hal tersebut tidak bisa dilakukan penulis pada sebuah tulisan terhadap pembacanya. Oleh karena itu kemampuan menulis sangatlah penting untuk dikuasai oleh mahasiswa untuk menghasilkan sebuah tulisan yang baik dan berkualitas dan harus mampu mengatasi kendala-kendala yang menjadi image menakutkan yang melekat pada waktu belajar menulis.

Pencapaian dalam kemampuan menulis tentu saja melalui proses yang panjang dalam belajar dan pemberian materi mengingat tingkat kesulitannya yang cukup tinggi pula, oleh karena itu mata kuliah menulis diberikan secara bertingkat sejak mereka berada di semester satu sampai dengan semester enam yang diberi nama Writing I sampai dengan Writing VI. Materi yang diberikan pun akan diberikan secara bertingkat pula untuk penguasaan pengetahuan dan teknik menulis ilmiah. Pada pembelajaran Writing I dan II mahasiswa diberikan materi dasar menulis yang berkaitan dengan pengenalan jenis kalimat, tanda baca, kohesi dan jenis-jenis paragraf dengan luaran yang diharapkan adalah sebuah tulisan berupa paragraf atau teks yang koheren. Setelah mahasiswa memasuki semester tiga dan empat, mereka diberikan mata kuliah Writing III dan IV, mereka dibekali dengan materi pengenalan academic writing yang mempelajari tentang berbagai macam jenis tulisan atau academic writing, cara mengutip teori, memaparkan referensi dan menghindari plagiat dan luaran yang diharapkan adalah mahasiswa mampu menghasilkan tulisan karya ilmiah berupa 
abstract, paper, article, essay dan mampu membuat tulisan sesuai kaidah ilmiah untuk tugas-tugas mata kuliah lainya serta mampu menghasilkan tulisan untuk kompetisikompetisi baik di tingkat lokal, regional maupun nasional seperti PKM. Setelah mahasiswa menduduki semester lima dan enam, mereka diberikan materi academic writing pada mata kuliah Writing V dan VI berupa laporan penelitian berkaitan dengan metodologi penelitian yang luarannya menghasilkan sebuah tulisan berupa proposal yang akan mereka teruskan sebagai tugas akhir mereka berupa skripsi.

Salah satu tujuan untuk mempelajari academic writing pada mata kuliah writing III adalah untuk menghasilkan karya ilmiah yang sangat diharapkan bisa berguna bagi mahasiswa untuk mengikuti kompetisi antar mahasiswa baik di tingkat lokal universitas, regional maupun nasional selain mahasiswa mampu menghasilkan karya ilmiah berupa artikel, esai, maupun paper yang sering menjadi tugas bagi mahasiswa dari mata kuliah yang lain secara berkualitas dan diproyeksikan mampu merambah di dunia publikasi. Karya ilmiah sendiri merupakan sebuah karya atau tulisan yang dihasilkan berdasarkan ilmu yang diperoleh dan dilakukan atau disusun melalui cara mengamati, menguji teori, memberikan tes, maupun mewancarai. Menurut Eko Susilo (1995: 11) Karya tulis ilmiah merupakan suatu karangan atau tulisan yang diperoleh sesuai dengan sifat keilmuannya dan didasari oleh hasil pengamatan, peninjauan, penelitian dalam bidang tertentu, disusun menurut metode tertentu dengan sistematika penulisan yang bersantun bahasa dan isinya dapat dipertanggungjawabkan kebenarannya/ keilmiahannya.

Mengingat pentingnya materi academic wrtiting bagi mahasiswa sebagai bekal utama mereka untuk bisa menghasilkan karya ilmiah yang berkualitas dan tingkat kesuliatan dalam penguasaan ketrampilan menulis, maka peneliti tertarik untuk meneliti pelaksanaan proses belajar mengajar Writing III dengan materi academic writing yang diberikan kepada mahasiswa semester empat di program studi pendidikan bahasa Inggris di universitas Widya Dharma Klaten untuk mengetahui strategi yang digunakan untuk mengajar academic writing.

Penelitian ini dilakukan dengan tujuan untuk menjawab pertanyaan yang diformulasikan dalam rumusan masalah, yaitu "Bagaimanakah proses pengajaran materi Academic Writing guna meningkatkan kualitas karya ilmiah bagi mahasiswa program studi pendidikan bahasa Inggris semester tiga di Universitas Widya Dharma Klaten?"

\section{ACADEMIC WRITING}

Academic writing adalah hal pokok dari menulis yang harus dilakukan di pendidikan di universitas. Di beberapa institusi mungking akan memeberikan lnama yang berbeda untuk academic writing (essay, paper, research paper, term paper, argumentative paper/essay, analysis paper/essay, informative essay, position paper), tapi dari semua istilah itu mempunyai tujuan dan prinsip yang sama (Whitaker, 2009: 2). Sementara itu Academic writing dapat didefinisikan sebagai besarnya isu yang berkembang akan pergeseran dan perubahan yang menjadi kebutuhan sebagai bekal menulis di kalangan pendidikan tinggi dan menjadi hal yang sangat diperhatikan sebagai syarat bagi perubahan baik di bidang pedagogi maupun metodologi. (Haggis, 2006).

\section{STRATEGI MENGAJAR ACADEMIC WRITING}

Menurut Bailey (2006) materi academic writing yang harus diberikan untuk mahasiswa adalah proses menulis, elemen menulis, keakuratan menulis, model menulis yang meliputi topik pembahasan tentang perencanaan, pengorganisasian paragraf, menulis introduction, main body dan conclusion. Selain mempelajari grammar, jenis-jenis kalimat, kohesi, jenisjenis academic writing, cara mengutip, memparafrase teori, editing, merevisi, menghindari plagiarism dan publikasi. 
Oshima dan Hogue (1998) menyatakan materi academic writing yang ideal adalah penulisan paragraf, menulis esai yang diajarkan secara bertahap, struktur kalimat yang diajarkan bersama-sama dalam pembahasan paragraf dan esai, dan jenisjenis kalimat.

Strategi mengajar Academic Writing di kelas yang sangat mudah dilakukan oleh pengajar untuk meningkatkan kompetensi mahasiswa di rujuk oleh Bean (2001) beberapa strategi mengajar mudah bias diterapkan di dalam kelas. Meliputi meminta respon mahasiswa dari beberapa pertanyaan yang sudah disediakan oleh pengajar diawal perkuliahan berdasarkan dari bacaan dan mengantisipasi ide yang muncul ketika memulai perkuliahan. Hal senada juga dipaparkan oleh Bean (2001) and Angelo and Cross (1993) mengundang atau meminta mahasiswa untuk berani bertanya tentang beberapa hal yang menjadi kesulitan mereka selama mengikuti perkuliahan writing dalam mengumpulkan ide. Bean (2001) juga menyarankan untuk meminta mahasiswa mencatat segala sesuatu yang menarik dan menjadi topik bahasan hangat ketika diskusi sedang berlangsun. Sebagai tambahan, Angelo and Cross (1993) and Bean (2001) merekomendasikan kepada mahasiswa untuk membuat ringkasan tentang segala sesuatu tentang materi yang mereka pahami dari perkuliahan dan menyusun dalam bentuk tulisan atau paragraf di akhir perkuliahan. Semua strategi ini membantu mahasiswa untuk memperdalam pengetahuan mereka dalam menentuka subyek atau topik tulisan dan mampu mengembangkan dalam bentuk tulisan atau paragraf yang kompleks dan detail. Mahasiswa juga mendapatkan kelebihan dalam meningkatkan kemampuan maya atau imaginative mereka dalam mengikuti perkuliahan dan mampu memberikan respon yang positif.

\section{KARYA ILMIAH}

Karya ilmiah adalah karangan ilmu pengetahuan yang menyajikankan fakta dan ditulis menurut metodologi penulisan yang baik dan benar (Haryanto, 2000). Brotowidjoyo (1995: 8-9) Karya Ilmiah adalah karangan ilmu pengetahuan yang menyajikan fakta dan ditulis menurut metodologi penulisan yang baik dan benar. Penulisan Ilmiah adalah karya tulis yang disusun oleh seorang penulis berdasarkan hasil-hasil penelitian ilmiah yang telah dilakukannya. Dari definisi yang lain dikatakan bahwa karya ilmiah (scientific paper) adalah laporan tertulis dan dipublikasi yang memaparkan hasil penelitian atau pengkajian yang telah dilakukan oleh seseorang atau sebuah tim dengan memenuhi kaidah dan etika keilmuan yang dikukuhkan dan ditaati oleh masyarakat keilmuan (Dwiloka dan Riana, 2005: 1-6). Wahyu (2001: 61) mengatakan bahwa "suatu karangan dapat dikatakan ilmiah jika ia mengungkapkan suatu permasalahan dengan metode ilmiah”. Maryadi (2001: 14) mendefinisikan karya ilmiah yaitu "suatu karya yang memuat dan mengkaji suatu permasalahan tertentu dengan menggunakan kaidah-kaidah keilmuan".

Nazir (1988) menjelaskan bahwa karya ilmiah disusun dengan menggunakan metode ilmiah, yaitu cara menerapkan prinsip-prinsip logis terhadap penemuan, pengesahan dan penjelasan tentang suatu kebenaran. Adapun kriteria metode ilmiah adalah: a. Berdasarkan fakta (bukan kirakira, khayalan, legenda) b. Bebas dari prasangka (tidak subyektif) c. Menggunakan prinsip-prinsip analisis (kausalitas \& pemecahan masalah berdasarkan analisis yang logis) d.Menggunakan hipotesis (sebagai pemandu jalan pikiran menuju pencapaian tujuan) e. Menggunakan ukuran obyektif (bukan berdasarkan perasaan) f. Menggunakan teknik kuantifikasi (nominal, rangking, rating).

Menurut Haryanto dkk (2000: 7) ciri karangan ilmiah meliputi: Menyajikan fakta objektif secara sistematis, pernyataanya cermat, tepat, tulus, dan benar serta tidak memuat terkaan, penulisanya tidak mengejar keuntungan pribadi, penyusunanya dilaksanakan secara 
sistematis, konseptual, dan prosedural, tidak memuat pandangan-pandangan tanpa kandungan fakta, tidak emotif menonjolkan perasaan, tidak bersifat argumentatif, tetapi kesimpulanya terbentuk atas dasar fakta. Sementara menurut Dwiloka dan Riana (2005: 4-5) sifat karangan ilmiah ialah: Lugas dan tidak emosional, logis, efektif, efisien, ditulis dengan bahasa Indonesia yang baku.

Jenis karya ilmiah berdasarkan sifat dan jenis penalaran yang digunakan, makalah dibedakan menjadi tiga macam, yaitu makalah deduktif, makalah induktif dan makalah campuran. Makalah deduktif merupakan makalah yang penulisannya didasarkan pada kajian teoritis (pustaka) yang relevan dengan masalah yang dibahas. Makalah induktif adalah makalah yang disusun berdasarkan data empiris yang diperoleh dari lapangan yang relevan dengan masalah yang dibahas. Makalah campuran adalah makalah yang penulisannya didasarkan pada kajian teoretis digabungkan dengan data empiris yang relevan dengan masalah yang dibahas. Dalam pelaksanaannya, jenis makalah pertama merupakan jenis makalah yang paling banyak digunakan (Dwiloka dan Riana, 2005: 97-98). Karya ilmiah di perguruan tinggi, menurut Arifin (1998), dibedakan menjadi: a. Makalah adalah karya tulis ilmiah yang menyajikan suatu masalah yang pembahasannya berdasarkan data di lapangan yang bersifat empiris-objektif. b. makalah menyajikan masalah dengan melalui proses berpikir deduktif atau induktif.Kertas kerja seperti halnya makalah, adalah juga karya tulis ilmiah yang menyajikan sesuatu berdasarkan data di lapangan yang bersifat empiris-objektif. Analisis dalam kertas kerja lebih mendalam daripada analisis dalam makalah. c. Skripsi adalah karya tulis ilmiah yang mengemukakan pendapat penulis berdasarkan pendapat orang lain. Pendapat yang diajukan harus didukung oleh data dan fakta empiris-objektif, baik bedasarkan penelitian langsung (obsevasi lapangan, atau percobaan di laboratorium), juga diperlukan sumbangan material berupa temuan baru dalam segi tata kerja, dalil-dalil, atau hukum tertentu tentang salah satu aspek atau lebih di bidang spesialisasinya. d. Tesis adalah karya tulis ilmiah yang sifatnya lebih mendalam dibandingkan dengan skripsi. Tesis mengungkapkan pengetahuan baru yang diperoleh dari penelitian sendiri. e. Disertasi adalah karya tulis ilmiah yang mengemukakan suatu dalil yang dapat dibuktikan oleh penulis berdasarkan data dan fakta yang sahih (valid) dengan analisis yang terinci). Disertasi ini berisi suatu temuan penulis sendiri, yang berupa temuan orisinal. Jika temuan orisinal ini dapat dipertahankan oleh penulisnya dari sanggahan penguji, penulisnya berhak menyandang gelar doktor (S3).

\section{METODE PENELITIAN}

Penelitian yang akan dilakukan ini merupakan penelitian kualitatif untuk mengetahui proses pengajaran materi Academic Writing dan mengidentifikasi kendala dan faktor pendukung yang dihadapi oleh mahasiswa program studi pendidikan bahasa Inggris semester III di universitas Widya Dharma Klaten. Penelitian ini merupakan penelitian studi kasus yang merupakan salah satu bagian penelitian kualitatif yang akan dilaksanakan melalui pengamatan, wawancara, diskusi, dan dokumentasi seperti yang dikemukakan oleh Lincoln dan Cuba (1985: 244) prosedur penelitian kualitatif sebagian besar dilakukan dengan catatan lapangan, pengamatan, percakapan, sejarah hidup dan wawancara yang didokumentasikan. Sedangkan Gall, dkk (2003: 435) menyatakan penelitian kualitatif disebut juga penelitian case study. Penelitian Case study melibatkan pendekatan khusus pada penyelidikan ilmiah. Penelitian ini dilakasanakan dengan subyek Mahasiswa semester III program studi pendidikan bahasa Inggris universitas Widya Dharma Klaten. 


\section{PEMBAHASAN}

Berdasarkan data yang diperoleh oleh peneliti melalui pengamatan, wawancara dan dokumentasi dapat dijelaskan strategi, media dan evaluasi pembelajaran sebagai berikut:

\section{Strategi Pembelajaran}

Strategi pembelajaran yang dilakukan oleh dosen Writing III untuk mengajar academic writing dalam satu semester adalah:

\section{A. Membaca}

Mahasiswa dimotivasi untuk membaca sebanyak-banyaknya dari berbagai sumber yang berbeda dan jenis teks yang bervariasi. Setelah mahasiswa mendapatkan pengetahuan dan referensi yang cukup, mahasiswa kemudian diarahkan untuk berdiskusi tentang topik-topik atau isu yang sedang terjadi untuk melatih kemampuan berfikir mereka.setiap mahasiswa diharuskan memberikan topik yang telah mereka peroleh dari proses membaca yang menurut mereka menarik untuk didiskusikan dan harus diberikan tanggapan oleh teman-teman mereka, pada tahap ini mereka melakukan satu-persatu secara bergantian. Kegiatan membaca merupakan cara yang efektif utuk membangun sebuah konsep menulis pada tahap awal perkuliahan yang diharapkan menjadi motivasi bagi mahasiswa dalam menulis mereka akan memperbanyak pengetahuan dan referensi dengan membaca. Kegiatan ini dilakukan pada setiap awal atau sebelum menulis pada proses pre writing.

\section{B. Fokus pada Text}

Pada tahap ini mahasiswa dikenalkan dengan berbagai macam teks atau tulisan Ilmiah, pada proses ini mahasiswa harus membuat pengamatan terhadap teks secara kritis dan mendiskusikan tentang struktur teks/outline. Setelah mengidentifikasi struktur teks, mahasiswa harus menyalin outline dari beberapa jenis teks yang berbeda. Kemudian mahasiswa diajarkan untuk mensitasi, memparafrase, mensisntesis beberapa teori yang ditemukan di dalam teks. Proses terakhir pada tahap ini adalah analisis aspek linguistik teks atau analisis tentang penyusunan, tata bahasa, koherensi dan mekanik dalam menulis. Keahlian yang dibangun pada tahap ini dilakukan oleh dosen sekitar enam tatap muka perkuliahan.

\section{Fokus pada Proses}

Pada pertemuan berikutnya mahasiswa diberikan beberapa teknik menulis yang berfokus pada proses menyusun sebuah tulisan, tahap pertama pada pre writing, mahasiswa diajak untuk melakukan brainstorming dan menulis bebas, pada kegiatan ini mahasiswa mencari ide menulis setelah kegiatan membaca atau diskusi, setelah mendapatkan ide mereka melanjutkan menulis secara bebas dan dilatih untuk memperhatikan aspek linguistiknya. Langkah berikutnya adalah menulis jurnal pribadi, jurnal yang dibuat oleh mahasiswa memuat tentang ide-ide yang muncul secara tiba-tiba dan menjadi catatan kecil tentang poin atau inti dari topik yang akan mereka kembangkan dalam tulisan untuk menjadi sebuah teks atau naskah. Mahasiswa juga bias menggunakan jurnal sebagai bahan pengamatan, refleksi dan mengembangakan pertanyaanpertanyaan sebagai langkah awal untuk menyusun sebuah tulisan akademik atau ilmiah. Berdasarkan jurnal yang disusun, mahasiswa melanjutkan kegiatan dengna membuat draf tulisan yang memuat ide-ide pokok yang sudah ditemukan. Apabila mahasiswa telah selesai membuat draf, tahap berikutnya adalah melakukan peer review atau penilaian sejawat terhadap tulisan yang sudah dibuat yang dilakukan oleh sesama mahasiswa. Tujuan dari kegiatan ini adalah untuk memberikan umpan balik dari masing-masing mahasiswa dan melatih mereka untuk menganalisis kekurangan dan kelemahan dalam sebuah tulisan ilmiah, dengan mengetahui letak kekurangannya berarti mahasiswa sudah menguasau teknik menulis dengan benar. Tahap berikutnya adalah proofreading/membaca ulang draf dan editing/menyunting kesalahan-kesalahan yang sudah berhasil diidentifikasi dari proses peer review. Tahap terakhir pada 
tahap ini adalah menulis dengan cara berkolaborasi, mahasiswa melanjutkan draf mereka dengan diberi kebebasan untuk berdiskusi dan memberikan saling memberi masukan berdassarkan pengetahuan dan keahlian masing-masing.

\section{Media Pembelajaran}

Berdasarkan temuan yang diperoleh peneliti melalui observasi atau pengamatan dapat digambarkan dalam mengajar academic writing dosen mata kuliah Writing III menggunakan media Internet BasedResources yang berfokus pada penggunaan internet sebagai sumber belajar secara optimal dan menggunakan aplikasi berbasis komputer untuk mengembangkan tulisan mereka. Aplikasi yang digunakan oleh mahasiswa adalah Google docs. Pada aplikasi google docs, mahasiswa dapat menyimpan dokumen yang bias diakses sewaktu-waktu tanpa hambatan, selain itu mahasiswa dapat dengan mudah melakukan penyuntingan, format ulang mebuat tabel dan gambar, menambahkan tautan yang diperlukan dengan mudah. Mereka dapat menulis dalam waktu yang sama dan membagikan kepada teman-temanya untuk melakukan peer review dan penyuntingan secara langsung, dalam proses penyuntingan mahasiswa dapat melakukan percakapan untuk memberikan catatan, komentar, dan melakukan diskusi. penggunaan google docs sangat kompatibel dengan dokumen word. Dengan menggunakan google docs, mahasiswa juga dituntut untuk mahir dalam menggunakan teknologi untuk mempermudah proses menulis dan mampu meminimalisir kerusakan dan kehilangan dokumen.

\section{Evaluasi Pembelajaran}

\section{A. Melengkapi naskah Academic Writing}

Jenis evaluasi ini mahasiswa harus melakukan beberapa tahapan untuk menyalesaikan sebuah naskah atau teks secara utuh, langkah pertama adalah memperhatikan konteks sebuah draf teks, mahasiswa diharuskan mengidentifikasi topik yang ada pada draf dan mengembangkan pengetahuan yang ada kaitanya dengan topik dengan cara membaca beberapa referensi yang bersumber pada internet, setelah merasa cukup untuk melengkapi draf maka mahasiswa harus melanjutkan menulis draf menjadi sebuah teks utuh. Penilaian dilakukan dengan menilai apakah teks yang dikembangakan sesuai dengan konteks yang sudah diidentifikasi pada draf. Tahap berikutnya adalah model dan demonstrasi, penilaian selanjutnya memperhatikan apakah mahasiswa mampu mengidentifikasi beberapa aspek teks seperti jenis teks dan mampu mengembangakan secara utuh sesuai dengan kaidah teks.

\section{B. Menganalisis kosakata ilmiah}

Evaluasi ini fokus pada kemampuan mahasiswa untuk mengutip, memparafrase dan mensintesis kaliamat melalui identifikasi kosakata yang berkaitan dengan karya ilmiah untuk menghindari kegiatan plagiat karya orang lain. Langkah pertama mahasiswa harus membaca sebuah tulisan ilmiah dan menganalisis kosakata yang ditemukan dalam sebuah teori atau terminologi, setelah memahami arti kosakata tersebut mahasiswa diharuskan memparafrase dalam bentuk kalimat atau penjabaran yang menggunakan ungkapan atau ide sendiri, hal ini bermanfaat pada proses sitasi karena mahasiswa mampu mengkonstruksi kutipan tidak langsung dengan baik. Setelah mengutip beberapa teori yang telah diparafrase mahasiswa diharuskan untuk mensintesis beberapa teori menjadi satu paragraf yang menggunakan kalimat atau penjelasan sendiri.

\section{Menulis karya ilmiah secara bervariasi}

Mahasiswa harus menulis beberapa jenis katya ilmiah yang berbeda, evaluasi dilakuakn dengan mencermati apakah mahasiswa mampu menulis karya ilmiah sesuai jenis yang diminta dan memenuhi kaidah-kaidah ilmiah yang berlaku. Mahasiswa juga dievaluasi dengan menulis karya ilmiah baik secara kuantitatif maupun kualitatif. Kemampuan membuat grafik, 
diagram, tabel dan pelabelan data menjadi poin atau komponen penilaian.

\section{SIMPULAN}

Pembelajaran academic writing membutuhkan strategi khusus dan efektif mengingat materi academic writing cakupanya sangat banyak baik melingkupi aspek linguistik dan metodologi dalam menulis sebuah karya ilmiah. Strategi yang diterapkan harus mampu mengakomodasi kedua aspek untuk bisa menghasilkan sebuah karya yang memenuhi kaidah ilmiah. Berdasarkan data yang dihimpun peneliti melalui beberapa teknik pengumpulan data dapat disimpulkan bahwa pembelajaran yang dilakukan oleh dosen mata kuliah
Writing III dalam mengajar academic writing di program pendidikan bahasa Inggris Universitas Widya Dharma Klaten yang mengadopsi dari teori Coffin, dkk (2005) dan pemilihan media pembelajaran mampu memeberikan pemahaman yang signifikan tentang academic writing dan memberikan hasil tulisan berupa karya ilmiah yang bervariasi dan memenuhi kaidah ilmiah, hal ini dibuktikan dari portofolio berupa tulisan mahasiswa selama satu semester mengikuti perkuliahan Writing III. Adapun kendala yang dihadapi oleh mahasiswa dan dosen pada garis besarnya adalah waktu pembelajaran yang kurang. Strategi yang diterapkan membutuhkan waktu yang banyak.

\section{DAFTAR PUSTAKA}

Angelo, T.A., \& Cross, K.P. 1993. Classroom Assessment Technique: A Handbook for College Teachers. San Fransisco: Jossey-Bass Publishers.

Arifin, E. Zaenal. 1998. Dasar-Dasar Penulisan Karya Ilmiah. Jakarta: Grasindo

Bailey, Stephen. 2006. Academic Writing: A Handbook for International Students, Second Edition. New York: Routledge.

Bean, J. C. 2001. Engaging ideas. San Francisco: Jossey Bass.

Brotowidjoyo, Mukayat D. 1995. Penulisan Karangan Ilmiah. Jakarta: Akademika Pressindo. Coffin, Caroline, et al. 2005. Teaching Academic Writing: A Toolkit for Higher Education. New York: Rouletdge.

Dwiloka, Bambang dan Rati Riana. 2005. Teknik Menulis Karya Ilmiah, Jakarta: PT Rineka Cipta, Cet. 1

Eko Susilo. 1995. Teknik Menulis Karya Ilmiah. Jakarta.

Fabb, N. and Durant, A. 2005. How to write essays and dissertations: a guide for English literature students. 2nd edn. Harlow: Longman.

Gall, Meredith. D., Gall, Joyce.P., \& Borg, Walter, R. 2003. Educational Research. United State of America: Pearson Education.

Haggis, T. 2006. Pedagogies for Diversity: Retaining Critical Challenge Admidst Fears of Dumbing Down Studies in Higher Education. 31 (5) pp 521-535.

Haryanto, A. G., dkk. 2000. Metode Penulisan dan Penyajian Karya Ilmiah: Buku Ajar untuk Mahasiswa. Jakarta: EGC.

Harmer, Jeremy. 1998. How to teach English. Britain: Longman

Lincoln and Guba. 1985. Naturalistic Theory. California: Sage Publication, Inc.

Maryadi. 2001. Pengertian dan Kriteria Karya Ilmiah. Dalam Harun, dkk. (Eds.), Pembudayaan Penulisan Karya Ilmiah (hlm. 13-14). Surakarta: Universitas Muhammadiyah Surakarta.

Miles, Mathew. B. \& Huberman, A. Michael. 1985. Qualitative Data Analysis. Arizona: Sage Publication, Inc.

Nazir, M. .1988. Metodologi Penelitian,Jakarta: Ghalia Indonesia.

Oshima, Alice. And Hogue, Ann. 1998. Writing Academic English, $3^{\text {rd }}$ Edition. New York: Longman. 
Soeparno. 2005. Bahasa Indonesia Untuk Penulisan Karya Ilmiah. Makalah Disampaikan Dalam Kegiatan Pelatihan Penulisan Bahan Kuliah (Buku Pegangan Kuliah), Jurusan AP FIP UNY, 16-20 Mei 2005.

Tatang, M. Amirin. 2006. Menulis Karya Ilmiah (Artikel). Makalah Pelatihan Penulisan Karya Ilmiah Bagi Guru-guru se-Indonesia. Yogyakarta, 2-3 November.

Wahyu, Wibowo. 2001. Manajemen Bahasa Pengorganisasian Karangan Pragmatik dalam Bahasa Indonesia untuk Mahasiswa dan Praktisi Bisnis. Jakarta: Gramedia Pustaka Utama.

Whitaker, Anne. 2009. Academic Writing Guide. Slovakia: City University. 